Review

\title{
PRECLINICAL STUDIES ON PLEIOTROPIC FUNCTIONS OF ERYTHROPOIETIN ON BONE HEALING
}

\author{
R. VASILEVA \& TS. CHAPRAZOV \\ Department of Veterinary Surgery, Faculty of Veterinary Medicine, \\ Trakia University, Stara Zagora, Bulgaria
}

\section{Summary}

Vasileva, R. \& Ts. Chaprazov, 2021. Preclinical studies on pleiotropic functions of erythropoietin on bone healing. Bulg. J. Vet. Med., 24, No 1, 1-11.

Erythropoietin (EPO) is a glycoprotein hormone, mainly known for its haemopoietic function. For orthopaedics, its pleiotropic effects - osteogenic and angiogenic potential, are of primary interest. The exact mechanism of EPO action is still unclear. The effects of EPO on bone healing were investigated through experiments with rats, mice, rabbits and pigs. Each of used models for experimental bone defects (calvarial models, long bone segmental defects, posterolateral spinal fusion and corticosteroid-induced femoral head osteonecrosis) has specific advantages and flaws. Obtaining specific and correct results is largely dependent on the used model. The brief evaluation of models could serve for standardisation of preclinical studies on bone regeneration.

Key words: bone defect, bone healing, erythropoietin (EPO), experimental models

\section{INTRODUCTION}

Erythropoietin $(\mathrm{EpO})$ is a glycoprotein hormone, mainly known for its haemopoietic function (Zubareva et al., 2019). EPO promotes the growth and development of erythrocyte precursors in bone marrow and increases erythrocyte counts (Coleman \& Brines, 2004; Debeljak et al., 2014; Uversky \& Redwan, 2017; Ganz, 2018; Perreault \& Venters, 2018). Therefore, the treatment with erythropoietin is a standard for management of EPOdeficient anaemia, seen in chronic renal failure patients (Hayat et al., 2008; Jelkmann, 2013).
The main source of EPO in adults is the peritubular renal cortex (Jelkmann, 2011). EPO gene expression was also detected in liver, lungs, spleen, brain, testes (Jelkmann \& Wagner, 2004), heart (Obara, 2008), uterus, placenta, ovaries (Yasuda, 2001) and hair follicles (Bodo, 2007). The secretion of EPO is controlled by hypoxia-inducible factors 1 and 2 (HIF-1 and HIF-2) in response to reduced oxygen supply of tissues (Jones \& Bergeron, 2001; Rankin et al., 2007; Keswani et al., 2011; Maiese et al., 2012). During the intrauterine development of foetuses, the main source of EPO is the liver (Zanjani 
et al., 1977; Dame et al., 1998; Jelkmann, 2001).

\section{EFFECTS OF ERYTHROPOIETIN ON MESENCHYMAL STEM CELLS AND BONE FORMATION}

Apart its physiological role for erythropoiesis control, EPO fulfills also a number of non-haemopoietic functions (Mocini et $a l ., 2007)$. During the last decades, the socalled pleiotropic functions of EPO were subject of research. Evidence for expression of EPO-receptors in the endothelium and smooth vascular muscles which promoted angiogenesis, wound healing and vascular protection was provided (Jaquet et al., 2002; Heeschen et al., 2003; Yaghobee et al., 2018). The protective effects of EPO on brain, heart and kidney tissues manifested by protection from stroke (Tsai et al., 2006), myocardial infarction (Cai et al., 2003; Calvillo et al., 2003; Moon et al., 2003; Parsa et al., 2003; Wright et al., 2004) and renal ischaemia (Ates et al., 2005) were reported. Its anti-inflammatory effect, attributed to the fact that EPO counteracts the action of some proinflammatory cytokines TNF $\alpha$ and IL-6 was also reported (Cervellini et al., 2013).

The osteogenic and angiogenic potential of erythropoietin are of particular interest for orthopaedics (Rölfing, 2014). Studies in this field have proved that EPO improved bone healing and could serve as a therapeutic means enhancing bone regeneration (Wan et al., 2014; Klontzas et al., 2016). The exact mechanism of action is still unknown. It is hypothesised that two pathways could be involved: direct and indirect. In the latter EPO binds to EPO-receptors on the surface of haemopoietic stem cells (HSCs), which activates a signalling pathway for synthesis of bone morphogenetic proteins (BMPs)
(Kim et al., 2012). The formation of BMPs, mainly BMP2 and BMP6, and their interaction with BMP-receptors, results in differentiation of bone progenitor cells into osteoblasts and stimulates callus formation (Sun et al., 2012). In the former mechanism, EPO exerts it effect on bone healing directly via bone marrow stromal cells (BMSCs), inducing their differentiation into osteoblasts (Suresh et al., 2019). Additionally, increased expression of the runt-related transcription factor 2 (Runx2) necessary for the growth of osteoblasts, accretion of minerals and increased activity of alkaline phosphatase, osteocalcin and bone sialoprotein is established (Shiozawa et al., 2010).

Some research reports suggest that EPO stimulates directly the precursors of osteoclasts and monocytes and induces bone resorption (Hiram-Bab et al., 2015; 2017; Orth et al., 2019). Nevertheless, the enhanced formation of osteoclasts triggered by EPO does not result in their activation, meaning that EPO induces osteoclastogenesis but did not influence osteoclastic function (Shiozawa et al., 2010).

The information presented so far allowed suggesting that EPO combines haemopoiesis and bone formation (McGee et al., 2012). Tens of experimental research studies have been conducted for more detailed investigation of EPO effects on bone healing. One group of studies have analysed the effect of systemic application of EPO through intraperitoneal (Holstein et al., 2007; Garcia et al., 2011; Yan et al., 2018) or subcutaneous injections (Bozlar et al., 2006; Rölfing et al., 2012). A second group has analysed the effect of its local application through EPO-soaked collagen or gelatin sponges (Rölfing et al., 2014) or its inclusion along with hyaluronic acid in microhydrogel (Hahn et al., 2007). A third group 
of researchers have investigated the effects of both the local and systemic application of EPO (Omlor et al., 2016; Li et al., 2018). The information for the possible regenerative effect of EPO applied on bone graft is scarce (Diker et al., 2018).

\section{ANIMAL MODELS USED IN THE STUDY OF ERYHTROPOIETIC EF- FECTS ON BONE HEALING - AD- VANTAGES AND SHORTCOMINGS}

The effects of local or systemic erythropoietin treatment on bone healing have been evaluated in models with various animal species: mice (Holstein et al., 2007; Holstein et al., 2011; Garcia et al., 2011), rats (Diker et al., 2018), rabbits (Rölfing et al., 2012; Omlor et al., 2016) and pigs (Rölfing et al., 2012).

\section{Rodents}

Rodents (mice and rats) are a preferred animal model in preclinical studies on bone regeneration (Gomes \& Fernandes, 2011). Their most important advantage is the possibility for using inbred lines, e.g. genetically identical laboratory animals from both sexes. The short duration of gestation (18-21 days) and rapid growth rate provide the necessary number of animals for experimental designs (Ostergaard et al., 2010).

Rodents are not a suitable alternative in long-term studies and for experimental designs with repeated collection of blood samples or biopsies due to the short life span and relatively small blood and tissue volume. The limitations of using these species as compared to rabbits and pigs are due to small size and the thin and frail cortex of their long bones (An \& Freidman, 1998).

\section{Rabbits}

Rabbits are used in research studies because of their small size, from one part, and due to similar bone mineral density of rabbits and humans from the other (Wang et al., 1998). It should be noted that there are substantial differences between these two species as anatomy (size and shape of bones) is concerned (Pearce et al., 2007). Another advantage of rabbits is that they attain skeletal maturity parallelly to sexual maturity at about 6 months of age (Gilsanz et al., 1988). In comparison to primates or rodents, in rabbits these changes in the skeleton and bone transformation occur faster (Castaneda et al., 2006).

\section{Pigs}

It is believed that pigs resemble humans as bone anatomy, morphology, remodelling, mineral density, concentration and bone regeneration events are concerned (Aerssens et al., 1998; Thorwarth et al., 2005). Pigs are appropriate animal models for critical size bone defects as their bone regeneration rate is comparable to that of men (Schlegel et al., 2006). Disadvantages of using pigs in orthopaedic research comprise rapid growth rate and high body weight (Pearce et al., 2007).

\section{EXPERIMENTAL BONE DEFECT MODELS FOR INVESTIGATION OF ERYTHROPOIETIN EFFECTS ON BONE HEALING}

In order to imitate orthopaedic states, defects have been created in various bones calvaria (Rölfing et al., 2012; Diker et al., 2018), radius (Omlor et al., 2016), femur (Holstein et al., 2007; Garcia et al., 2011), tibia (Bozlar et al., 2006).

Four primary bone defects models have been used in experiments evaluating 
bone healing after erythropoietin application. Every one has its advantages and drawbacks which should be considered when selecting a specific model of bone defect.

\section{Long bone defects}

The creation of critical size segmental long bone defect is the standard in studies on the osteogenetic potential of various materials. This bone defect should not heal spontaneously during the lifetime of the animal (Horner et al., 2010). By means of osteotomy, a bone segment is removed from a predetermined site. It is accepted that bone defect size should be 2-2.5 times larger than the bone diameter (ASTM, 2014). Its size is also influenced by other factors e.g. animal age and species, defect location, bone structure, presence of periosteum, mechanical loading of bone and bone metabolism, the condition of the animals, as well as bone fixation device used for stabilisation of the defect (Reichert et al., 2009; Glatt \& Matthys, 2014).

To evaluate the effect of EPO application on the healing of long tubular bones, models with closed fracture, osteotomy or ostectomy with creation of segmental bone defect have been used. When a rodent radius model is selected, the fracture may remain non-stabilised, whereas osteotomies in femoral or tibial diaphyses require additional bone fixation (Muschler et al., 2010). Studies are presented in Table 1 .

\section{Calvarial bone defect}

Calvarial defects are popular among researchers because the bone structure allows creating a standardised defect that could be then submitted to histological, radiological or computed tomography evaluation (Gomes \& Fernandes, 2011).

Table 1. Long bone models used in investigation on EPO effects on bone healing

\begin{tabular}{|c|c|c|c|c|}
\hline $\begin{array}{l}\text { Animal } \\
\text { species }\end{array}$ & Defect & EPO application & $\begin{array}{l}\text { Effect on bone } \\
\text { healing }\end{array}$ & References \\
\hline Rats & $\begin{array}{l}\text { Tibia, } \\
\text { osteotomy }\end{array}$ & $\begin{array}{l}\text { Systemic s.c. treatment } \\
\text { with EPO } 200 \mathrm{UI} / \mathrm{kg} \text { for } \\
7 \text { days }\end{array}$ & $\begin{array}{l}\uparrow \text { periosteal reaction } \\
\uparrow \text { bone union } \\
\uparrow \text { bone remodelling }\end{array}$ & $\begin{array}{l}\text { Bozlar et al., } \\
2006\end{array}$ \\
\hline Mice & $\begin{array}{l}\text { Femur, } \\
\text { closed frac- } \\
\text { ture }\end{array}$ & $\begin{array}{l}\text { Systemic i.p. treatment } \\
\text { with } 5000 \mathrm{UI} / \mathrm{kg} \text { EPO for } \\
5 \text { days }\end{array}$ & $\begin{array}{l}\uparrow \text { expression of EPOR } \\
\uparrow \text { callus density } \\
\uparrow \text { callus mineralisation } \\
\uparrow \text { torsional stiffness }\end{array}$ & $\begin{array}{l}\text { Holstein et } \\
\text { al., } 2007\end{array}$ \\
\hline Mice & $\begin{array}{l}\text { Femur, } \\
\text { segmental } \\
\text { defect }\end{array}$ & $\begin{array}{l}\text { Systemic i.p. treatment } \\
\text { with } 500 \mathrm{UI} / \mathrm{kg} \text { EPO for } \\
2 \text { or } 10 \text { weeks }\end{array}$ & $\begin{array}{l}\uparrow \text { bone formation } \\
\uparrow \text { bone volume } \\
\uparrow \text { vascularisation }\end{array}$ & $\begin{array}{l}\text { Holstein et } \\
\text { al., } 2011\end{array}$ \\
\hline Mice & $\begin{array}{l}\text { Femur, } \\
\text { osteotomy }\end{array}$ & $\begin{array}{l}\text { Systemic i.p. treatment } \\
\text { with } 500 \mathrm{UI} / \mathrm{kg} \text { EPO for } \\
2 \text { or } 10 \text { weeks }\end{array}$ & $\begin{array}{l}\uparrow \text { callus diameter } \\
\uparrow \text { callus mineralisation } \\
\uparrow \text { bone density }\end{array}$ & $\begin{array}{l}\text { Garcia et al., } \\
2011\end{array}$ \\
\hline \multirow[t]{2}{*}{ Rabbits } & \multirow{2}{*}{$\begin{array}{l}\text { Radius, } \\
\text { segmental } \\
\text { defect }\end{array}$} & $\begin{array}{l}\text { Single s.c. treatment with } \\
\text { EPO } 4900 \mathrm{UI} / \mathrm{kg}\end{array}$ & \multirow{2}{*}{$\begin{array}{l}\uparrow \text { bone formation } \\
\uparrow \text { bone volume } \\
\uparrow \text { vascularisation }\end{array}$} & \multirow[t]{2}{*}{$\begin{array}{l}\text { Omlor et al. } \\
2016\end{array}$} \\
\hline & & $\begin{array}{l}\text { Local application of EPO- } \\
\text { soaked gelatin sponges } \\
(4900 \mathrm{UI} / \mathrm{kg})\end{array}$ & & \\
\hline
\end{tabular}


The creation of calvarial defects is an easy procedure. It comprises a sagittal incision along the scalp surface and lifting of the skin flap. A critical size circular defect, most commonly on the parietal bone and comprising all layers is then made by trephination. Critical size bone defects are the smallest intraosseous defects that could not heal spontaneously during the life of an animal (Schmitz \& Hollinger, 1986). The critical size in mice is $3-5 \mathrm{~mm}$, in rats: $5-8 \mathrm{~mm}$ and in rabbits: $15 \mathrm{~mm}$ (Cooper et al., 2010). Two openings are usually created, one serving as control. The surgical procedure is terminated with removal of the bone fragment in order to preserve dura mater from injury. The periosteum is returned to its place and the skin is sutured (Nakamura et al., 2017).

The main advantage of the method is the possibility to introduce simultaneously the scaffold and EPO with a single approach without need from external fixation due to the pressure exerted by dura mater and skin (Gomes \& Fernandes, 2011). A flaw of this approach is the impossibility to evaluate the efficacy of EPO in mechanical loads, important in regeneration of load-bearing bones.

Rölfing et al. (2012) performed a research to evaluate the effect of single local application of EPO on collagen carrier at the site of defects created by trephination in porcine skull bones. The results were assessed by the $5^{\text {th }}$ post treatment week and demonstrated enhanced healing of skull bones, increased bone volume and enhanced vascularisation. Using a similar experimental design in rats, Diker et al. (2018) studied the effect from systemic intraperitoneal application of EPO at 500 $\mathrm{UI} / \mathrm{kg}$ after creation of 5-mm trephination openings and placements of a heterologous xenograft in one of defects. The re- sults showed that the treatment with EPO alone has no effects on angiogenesis and bone formation in minimally critical bone defects by the end of the $4^{\text {th }}$ week. The authors concluded that the systemic application of EPO could be successful as complementary therapy in xenografting.

\section{Posterolateral spinal fusion}

Rabbit spinal fusion model is widely used in research aiming to evaluate the effect of various biomaterials on bone formation at the site of bone defects. It consists in making a skin incision along the median line of the back, dissection of $\mathrm{m}$. multifidus and $\mathrm{m}$. longissimus dorsi to reach the transverse processes of L5 and L6. By means of a high-speed burr, transverse processes are decorticated at a distance of $10 \mathrm{~mm}$ from their base (Walsh et al., 2009). The tested material is placed in thus created defect. By the end of the intervention, tissues are sutured layer by layer (Virk et al., 2016).

This model is applied in an attempt to demonstrate the effect of systemic treatment with EPO on bone healing. Rölfing et al. (2012) used a experimental design with rabbits submitted to posterolateral spinal fusion and placement of autograft from the iliac crest at the site of the defect. Over 20 days, rabbits were subcutaneously injected with low doses of erythropoietin $-250 \mathrm{UI} / \mathrm{kg}$. By the $6^{\text {th }}$ week post surgery, computed tomography and radiography demonstrated increased bone volume, whereas histomorphometry provided evidence for enhanced vascularisation. Haematopoietic potential of EPO was confirmed by blood samples collected on post operative weeks 2,4 and 6 for measurement of haemoglobin and haematocrit values. 


\section{Corticosteroid-induced femoral head osteonecrosis}

Continuous therapy with corticosteroids could result in osteonecrosis of the femoral head. The most popular hypothesis is that the hypertrophy of bone marrow adipocytes increases the pressure in bone marrow, thus reducing the blood flow in sinusoids and causing ischaemia. Glucocorticoids may have a direct toxic effect on bone cells and thus, play an important role in apoptosis (He et al., 2016).

Corticosteroid-induced femoral head osteonecrosis in rodents could be reproduced by adding dexamethasone to drinking water over 15 weeks: $4 \mathrm{mg} / \mathrm{L}$ during the first week and $2 \mathrm{mg} / \mathrm{L}$ during the remaining period (Yang et al., 2009), through intramuscular injection of 20 $\mathrm{mg} / \mathrm{kg}$ methylprednisolone twice a week over 6 weeks (Yan et al., 2018) or using slow-release prednisolone implants of 2.1 $\mathrm{mg} / \mathrm{kg} /$ day (Weinstein et al., 2017).

Several studies were performed to show the therapeutic effect of erythropoietin applied simultaneously with corticosteroids to induce femoral head osteonecrosis. Li et al. (2018) used the model in rats. By the $8^{\text {th }}$ week after osteonecrosis reproduction, animals were euthanised and submitted to radiological, histological and histometrical examinations as well as Western Blot analysis. The obtained results proved that EPO application increased bone volume, the number of trabeculae, their thickness and separation. Also, enhanced expression of alkaline phosphatase and Runx2, HIF-1, and vascular endothelial growth factor (VEGF) at the site of osteonecrosis was demonstrated. The researchers concluded that local injection of EPO was more successful in mediating HIF-1 controlled osteogenic and angiogenic expression of factors and improved substantially the condition of animals.

These results were also confirmed by Yan et al. (2018) who reported that daily intraperitoneal injection of EPO resulted in enhanced VEGF expression and that the morphology of EPO-treated group was very similar to that of controls. These facts affirmed the protective effect of erythropoietin in corticosteroid-induced femoral head osteonecrosis (Yan et al., 2018).

\section{CONCLUSION}

The present literature overview is focused on most important models of bone defects used in studies evaluating the effect of local or systemic erythropoietin application on bone healing. Preclinical studies on laboratory animals are a prerequisite before proceeding with EPO application tests in clinical patients.

In vivo experimental studies allowed evaluating the effects, safety and possible unwanted responses after using a specific biomaterial for stimulation of bone formation. Experimental designs using smallsize animals have a number of advantages, therefore rats are a preferred animal species. The standardisation of surgical protocols in the study on various bone defects in animals would make the results from studies fully comparable.

\section{REFERENCES}

Aerssens, J., S. Boonen, G. Lowet \& J. Dequeker, 1998. Interspecies differences in bone composition, density, and quality: potential implications for in vivo bone research. Endocrinology, 139, 663-670.

An, Y. H. \& R. J. Freidman, 1998. Animal Models in Orthopaedic Research. CRC Press, Boca Raton, Florida. 
ASTM, 2014. Standard guide for pre-clinical in vivo evaluation in critical size segmental bone defects. ASTM International, West Conshohocken,

https://www.astm.org/Standards/F2721.ht m (6 April 2020 date last accessed)/

Ates, E., A. U. Yalcin, S. Yilmaz, T. Koken \& C. Tokyol, 2005 Protective effect of erythropoietin on renal ischemia and reperfusion injury. ANZ Journal of Surgery, 75, 1100-1105.

Bodo, E., A. Kromminga, W. Funk, M. Laugsch, U. Duske, W. Jelkmann \& R. Paus, 2007. Human hair follicles are an extrarenal source and a nonhematopoietic target of erythropoietin. FASEB Journal, 21, 3346-3354.

Bozlar, M., A. Kalaci, B. Aslan, L. Baktiroglu, A.N. Yanat \& A. Tasci, 2006. Effects of erythropoietin on fracture healing in rats. Saudi Medical Journal, 27, 1267-1269.

Cai, Z., D. J. Manalo, G. Wei, E. R. Rodriguez, K. Fox-Talbot, H. Lu, J. L. Zweier \& G. L. Semenza, 2003. Hearts from rodents exposed to intermittent hypoxia or erythropoietin are protected against ischemia-reperfusion injury. Circulation, 108, 79-85.

Calvillo, L., R. Latini, J. Kajstura, A. Leri, P. Anversa, P. Ghezzi, M. Salio, A. Cerami \& M. Brines, 2003. Recombinant human erythropoietin protects the myocardium from ischemia-reperfusion injury and promotes beneficial remodeling. Proceedings of the National Academy of Sciences of the USA, 100, 4802-4806.

Castaneda, S., R. Largo, E. Calvo, F. Rodriguez-Salvanes, M. E. Marcos, M. DiazCuriel \& G. Herrero-Beaumont, 2006. Bone mineral measurements of subchondral and trabecular bone in healthy and osteoporotic rabbits. Skeletal Radiology, 35, 34-41.

Cervellini, I., S. Sacre, P. Ghezzi \& M. Mengozzi, 2013. Erythropoietin does not affect TNF and IL-6 production directly. Journal of Biological Regulators and Homeostasis Agents, 27, 189-196.
Coleman, T. \& M. Brines, 2004. Science review: Recombinant human erythropoietin in critical illness: a role beyond anemia? Critical Care, 8, 337-341.

Cooper, G., M. Mooney, A. Gosain, P. Campbell, J. Losee \& J. Huard, 2010. Testing the critical size in calvarial bone defects: Revising the concept of a critical-size defects. Plastic and Reconstructive Surgery, 125, 1685-1692.

Dame, C., H. Fahnenstich, P. Freitag, D. Hofmann, T. Abdul-Nour, P. Bartmann \& J. Fandrey, 1998. Erythropoietin mRNA expression in human fetal and neonatal tissue. Blood, 92, 3218-3225.

Debeljak, N., P. Solar, A. Sytkowski, 2014. Erythropoietin and cancer: The unintended consequences of anemia correction. Frontiers in Immunology, 5, 563.

Diker, N., H. Sarican, A. Cumbul \& E. Kilic, 2018. Effects of systemic erythropoietin treatment and heterogeneous xenograft in combination on bone regeneration of a critical-size defect in an experimental model. Journal of Craniomaxillofacial Surgery, 46, 1919-1923.

Garcia, P., V. Speidel, C. Scheuer, M. W. Laschke, J. H. Holstein, T. Histing, T. Pohlemann \& M. D. Menger, 2011. Low dose erythropoietin stimulates bone healing in mice. Journal of Orthopedic Research, 29, 165-172.

Ganz, T., 2018. Erythropoietin and iron - a conflicted alliance? Kidney International, 94, 851-853.

Gilsanz, V., T. F. Roe, D. T. Gibbens, E. E. Schulz, M. E. Carlson, O. Gonzalez \& M. I. Boechat, 1988. Effect of sex steroids on peak bone density of growing rabbits. The American Journal of Physiology, 255, 416-421.

Glatt, V. \& R. Matthys, 2014. Adjustable stiffness, external fixator for the rat femur osteotomy and segmental bone defect models. Journal of Visualized Experiments, 92, e51558.

Gomes, P. S. \& M. H. Fernandes, 2011. Rodent models in bone-related research: The 
relevance of calvarial defects in the assessment of bone regeneration strategies. Laboratory Animals, 45, 14-24.

Hahn, S., J. Kim \& T. Shimobouji, 2007. Injectable hyaluronic acid microhydrogels for controlled release formulation of erythropoietin. Journal of Biomedical Materials Research. Part A, 80, 916-924.

Hayat, A., D. Haria \& M. O. Salifu, 2008. Erythropoietin stimulating agents in the management of anemia of chronic kidney disease. Patient Prefer Adherence, 2, 195-200.

He, M., J. Wang, G. Wang, Y. Tian, L. Jiang, Z. Ren, C. Qui \& Q. Fu, 2016. Effect of glucocorticoids on osteoclast function in a mouse model of bone necrosis. Molecular Medicine Reports, 14, 1054-1060.

Heeschen, C., A. Aicher, R. Lehmann, S. Fichtlscherer, M. Vasa, C. Urbich, C. Mildner-Rihm, H. Martin, A. M. Zeiher \& S. Dimmeler, 2003. Erythropoietin is a potent physiologic stimulus for endothelial progenitor cell mobilization. Blood, 102, 1340-1346.

Hiram-Bab, S., T. Liron, N. Deshet-Unger, M. Mittelman, M. Gassmann, M. Rauner, K. Franke, B. Wielockx, D. Neumann \& Y. Gabet, 2015. Erythropoietin directly stimulates osteoclast precursors and induces bone loss. FASEB Journal, 29, 1890-1900.

Hiram-Bab, S., D. Neumann \& Y. Gabet, 2017. Erythropoietin in bone - controversies and consensus. Cytokine, 89, 155-159.

Holstein, J. H., M. D. Menger, C. Scheuer, C. Meier, U. Culemann, R. J. Wirbel, P. Garcia \& T. Pohlemann, 2007. Erythropoietin (EPO): EPO-receptor signaling improves early endochondral ossification and mechanical strength in fracture healing. Life Sciences, 80, 893-900.

Holstein, J. H., M. Orth, C. Scheuer, A. Tami, S. C. Becker, P. Garcia, T. Histing, P. Mörsdorf, M. Klein, T. Pohlemann \& M. D. Menger, 2011. Erythropoietin stimulates bone formation, cell proliferation, and angiogenesis in a femoral segmental defect model in mice. Bone, 49, 1037 1045.

Horner, E., J. Kirkham, D. Wood, S. Curran, M. Smith, B. Thomson \& X. Yang, 2010. Long bone defect models for tissue engineering applications: criteria for choice. Tissue Engineering Part B. Reviews, 16, 263-271.

Jaquet, K., K. Krause, M. Tawakol-Khodai, S. Geidel, K-H. Kuck, 2002. Erythropoietin and VEGF exhibit equal angiogenic potential. Microvascular Research, 64, 326333.

Jelkmann, W., 2001. The role of the liver in the production of thrombopoietin compared with erythropoietin. European Journal of Gastroenterology \& Hepatology, 13, 791-801.

Jelkmann, W. \& K. Wagner, 2004. Beneficial and ominous aspects of the pleiotropic action of erythropoietin. Annals of Hematology, 83, 673-686.

Jelkmann, W., 2011. Regulation of erythropoietin production. The Journal of Physiology, 589, 1251-1258.

Jelkmann, W., 2013. Physiology and pharmacology of erythropoietin. Transfusion Medicine and Hemotherapy, 40, 302-309.

Jones, N. M. \& M. Bergeron, 2001. Hypoxic preconditioning induces changes in HIF-1 target genes in neonatal rat brain. Journal of Cerebral Blood Flow and Metabolism, 21, 1105-1114.

Keswani, S. C., M. Bosch-Marcé, N. Reed, A. Fischer, G. Semenza \& A. Hoke, 2011. Nitric oxide prevents axonal degeneration by inducing HIF-1-dependent expression of erythropoietin. Proceedings of the National Academy of Sciences of the USA, $\mathbf{1 0 8}$ 4986-4990.

Kim, J, Y. Jung, H. Sun, J. Joseph, A. Mishea, Y. Shiozawa, J. Wang, P. Krebsbach \& R. Taichman, 2012. Erythropoietin mediated bone formation is regulated by mTOR signaling. Journal of Cellular Biochemistry, 113, 220-228. 
Klontzas, M. E., E. I. Kenanidis, R. J. MacFarlane, T. Michail, M. E. Potoupnis, M. Heliotis \& E. Tsiridis, 2016. Investigational drugs for fracture healing: Preclinical \& clinical data. Expert Opinion on Investigational Drugs, 25, 585-596.

Li, D., Q. Hu, G. Tan, X. Xie, Z. Yang \& P. Kang, 2018. Erythropoietin enhances bone repair effects via the hypoxia-inducible factor signal pathway in glucocorticoidinduced osteonecrosis of the femoral head. The American Journal of the Medical Sciences, 355, 597-606.

Maiese, K., Z. Chong, Y. Shang, \& S. Wang, 2012. Erythropoietin: New directions for the nervous system. International Journal of Molecular Sciences, 13, 11102-11129.

McGee, S., A. Havens, Y. Shiozawa, Y. Jung \& R. Taichman, 2012. Effects of erythropoietin on the bone microenvironment. Growth Factors, 30, 22-28.

Mocini, D., T. Leone, M. Tubaro, M. Santini \& M. Penco, 2007. Structure, production and function of erythropoietin: Implications for therapeutical use in cardiovascular disease. Current Medicinal Chemistry, 14, 2278-2287.

Moon, C., M. Krawczyk, D. Ahn, I. Ahmet, D. Paik, E. G. Lakatta \& M. I. Talan, 2003. Erythropoietin reduces myocardial infarction and left ventricular functional decline after coronary artery ligation in rats. Proceedings of the National Academy of Sciences of the USA, 100, 1161211617.

Muschler, G. F., V. Raut, T. Patterson, J. Wenke \& J. Hollinger, 2010. The design and use of animal models for translational research in bone tissue engineering and regenerative medicine. Tissue Engineering. Part B, Reviews, 16, 123-145.

Nakamura, T., Y. Shirakata, Y. Shinohara, R. J. Miron, K. Hasegawa-Nakamura, M. Fujioka-Kobayashi \& K. Noguchi, 2017. Comparison of the effects of recombinant human bone morphogenetic protein-2 and -9 on bone formation in rat calvarial criti- cal-size defects. Clinical Oral Investigations, 21, 2671-2679.

Obara, N., N. Suzuki, K. Kim, T. Nagasawa, S. Imagawa \& M. Yamamoto, 2008. Repression via the GATA box is essential for tissue-specific erythropoietin gene expression. Blood, 111, 5223-5232.

Omlor, G. W., K. Kleinschmidt, S. Gantz, A. Speicher, T. Guehring \& W. Richter, 2016. Increased bone formation in a rabbit long-bone defect model after single local and single systemic application of erythropoietin. Acta Orthopaedica, 87, 425-431.

Orth, M., J. Baudach, C. Scheuer, D. Osche, N. Veith, B. Braun, M. Rollmann, S. Hearth, T. Pohlemann, M. Menger \& T. Histing, 2019. Erythropoietin does not improve fracture healing in aged mice. $E x$ perimental Gerontology, 122, 1-9.

Ostergaard, G., H. Hansen \& J. Ottesen, 2010. Physiological, hematological and clinical chemistry parameters, including conversion factors. In: Handbook of Laboratory Animal Science, Volume I: Essential Principles and Practices, Vol. 1, $3^{\text {rd }}$ edn, eds J. Hau \& S. J. Schapiro, CRC Press, Boca Raton, FL, pp. 667-707.

Parsa, C. J., A. Matsumoto, J. Kim, R. U. Riel, L. S. Pascal, G. B. Walton, R. B. Thompson, J. A. Petrofski, B. H. Annex, J. S. Stamler \& W. J. Koch, 2003. A novel protective effect of erythropoietin in the infarcted heart. Journal of Clinical Investigation, 112, 999-1007.

Pearce, A. I., R. G. Richards, S. Milz, E. Schneider \& S. G. Pearce, 2007. Animal models for implant biomaterial research in bone: A review. European Cells and $\mathrm{Ma}$ terials, 13, 1-10.

Perreault, A. A. \& B. J. Venters. 2018. Integrative view on how erythropoietin signaling controls transcription patterns in erythroid cells. Current Opinion in Hematology, 25, 189-195.

Rankin, E. B., M. P. Biju, Q. Liu, T. L. Unger, J. Rha, R. S. Johnson, M. C. Simon, B. Keith \& V. H. Haase, 2007. Hypoxiainducible factor-2 (HIF-2) regulates he- 
patic erythropoietin in vivo. Journal of Clinical Investigation, 117, 1068-1077.

Reichert, J., S. Saifzadeh, M. Wullschleger, D. Epari, M. Schutz, G. Duda, H. Schell, M. Van Griensven, H. Redl \& D. Hutmacher, 2009. The challenge of establishing preclinical models for segmental bone defect research. Biomaterials, 30, 2149-2163.

Rölfing, J., 2014. The effect of erythropoietin on bone, Acta Orthopaedica, 85, 1-29.

Rölfing, J., M. Bendtsen, J. Jensen, M. Stiehler, C. B. Foldager, M. B. Hellfritzsch \& C. Bünger, 2012. Erythropoietin augments bone formation in a rabbit posterolateral spinal fusion model. Journal of Orthopaedic Research, 30, 1083-1088.

Rölfing, J., J. Jensen, J. N. Jensen, A. Greve, H. Lysdahl, M. Chen, L. Rejnmark. \& C. Bünger, 2014. A single topical dose of erythropoietin applied on a collagen carrier enhances calvarial bone healing in pigs. Acta Orthopaedica, 85, 201-209.

Schlegel, K. A., F. J. Lang, K. Donath, J. T. Kulow \& J. Wiltfang, 2006. The monocortical critical size bone defect as an alternative experimental model in testing bone substitute materials. Oral Medicine, Oral Pathology, Oral Radiology and Endodontics, 102, 7-13.

Schmitz, J. P. \& J. O. Hollinger, 1986. The critical size defect as an experimental model for craniomandibulofacial nonunions. Clinical Orthopaedics and Related Research, 205, 299-308.

Shiozawa, Y., Y. Jung, A. M. Ziegler, E. A. Pedersen, J. Wang, Z. Wang, J. Song, J. Wang, C. H. Lee, S. Sud, K. J. Pienta, P. H. Krebsbach \& R. S. Taichman, 2010. Erythropoietin couples hematopoiesis with bone formation. PLoS One, 5, e10853.

Sun, H., Y. Jung, Y. Shiozawa, R. Taichman \& P. Krebsbach, 2012. Erythropoietin modulates the structure of bone morphogenic protein 2-engineered cranial bone. Tissue Engeneering Part A, 18, 2095-2105.

Suresh, S., L. Fernandes de Castro, S. Dey, P. Robey \& C. Noguchi, 2019. Erythro- poietin modulates bone marrow stromal cell differentiation. Bone Research, 7, 21.

Thorwarth, M., S. Schultze-Mosgau, P. Kessler, J. Wiltfang \& K. A. Schlegel, 2005. Bone regeneration in osseous defects using a resorbable nanoparticular hydroxyapatite. Journal of Oral and Maxillofacial Surgery, 63, 1626-1633.

Tsai, P. T., J. J. Ohab, N. Kertesz, M. Groszer, C. Matter, J. Gao, X. Liu, H. Wu \& S.T. Carmichael, 2006. A critical role of erythropoietin receptor in neurogenesis and post-stroke recovery. The Journal of Neuroscience., 26, 1269-1274.

Uversky, V. N. \& E. M. Redwan, 2017. Erythropoietin and co.: Intrinsic structure and functional disorder. Molecular BioSystems, 13, 56-72.

Virk, S., D. Coble, A. Bertone, H. Hussein \& S. Khan, 2016. Experimental design and surgical approach to create a spinal fusion model in a New Zealand white rabbit (Oryctolagus cuniculus). Journal of Investigative Surgery, 30, 1-9.

Wan, L., F. Zhang, Q. He, W.P. Tsang, L. Lu, Q. Li, Z. Wu, G. Qui, G. Zhou \& C. Wan, 2014. EPO promotes bone repair through enhanced cartilaginous callus formation and angiogenesis. PLoS One, 9 , e102010.

Wang, X., J. D. Mabrey \& C.M. Agrawal, 1998. An interspecies comparison of bone fracture properties. Biomedical Materials and Engineering, 8, 1-9.

Walsh, R. W., F. Vizesi, G. B. Cornwall, D. Bell, R. Oliver \& Y. Yu, 2009. Posterolateral spinal fusion in a rabbit model using a collagen-mineral composite bone graft substitute. European Spine Journal, 18, 1610-1620.

Weinstein, R., E. Hogan, M. Borrelli, S. Liachenko, C. O'Brien \& S. Manolagas, 2017. The pathophysiological sequence of glucocorticoid-induced osteonecrosis of the femoral head in male mice. Endocrinology, 158, 3817-3831.

Wright, G. L., P. Hanlon, K. Amin, C. Steenbergen, E. Murphy \& M. O. Arcasoy, 2004. Erythropoietin receptor expression 
in adult rat cardiomyocytes is associated with an acute cardioprotective effect for recombinant erythropoietin during ischemia-reperfusion injury. FASEB Journal, 18, 1031-1033.

Yaghobee, S., N. Rouzhmen, H. Aslroosta, S. Mahmoodi, A. Khorsand \& M. Kharrazifard, 2018. Effect of topical erythropoietin (EPO) on palatal wound healing subsequent to free gingival grafting (FGG). Brazilian Oral Research, 32, 0052.

Yan, Y., Q. Pang \& R. Xu, 2018. Effects of erythropoietin for precaution of steroidinduces femoral head necrosis in rats. BMC Musculoskeletal Disorders, 19, 282.

Yang, L., K. Boyd, S. C. Kaste, L. K. Kamdem, R. J. Rahija \& M.V. Relling, 2009. A mouse model for glucocorticoid-induced osteonecrosis: Effect of a steroid holiday. Journal of Orthopaedic Research, 27, 169-175.

Yasuda, Y., Y. Fujita, T. Musha, H. Tanaka, S. Shiokawa, K. Nakamatsu, S. Mori, T. Matsuo \&Y. Nakamura, 2001. Expression of erythropoietin in human female reproductive organs. Italian Journal of Anatomy and Embryology, 106, 215-222.
Zanjani, E. D., J. Poster, H. Burlington, L. I. Mann \& L. R. Wasserman, 1977. Liver as the primary site of erythropoietin formation in the fetus. Journal of Laboratory and Clinical Medicine, 89, 640-644.

Zubareva, E., S. Nedezhdin, Y. Burda, N. Nadezhdina \& A. Gashevskaya, 2019. Pleiotropic effects of erythropoietin. Influence of erythropoietin on processes of mesenchymal stem cells differentiation. Research Results in Pharmacology, 5, 5366.

Paper received 22.01.2020; accepted for publication 27.03.2020

\section{Correspondence:}

Radina Vasileva

Department of Veterinary Surgery,

Faculty of Veterinary Medicine,

Trakia University,

6000 Stara Zagora, Bulgaria

e-mail: dr.vasileva@yahoo.com 